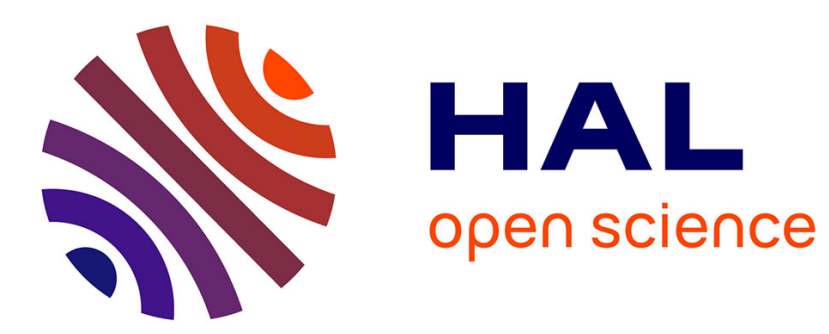

\title{
Analysis of beams from a dynamitron accelerator with a view to modification for high precision electron and positive ion operation
}

\author{
R. Bassett
}

\section{- To cite this version:}

R. Bassett. Analysis of beams from a dynamitron accelerator with a view to modification for high precision electron and positive ion operation. Revue de Physique Appliquée, 1977, 12 (10), pp.14181418. 10.1051/rphysap:0197700120100141800 . jpa-00244338

\section{HAL Id: jpa-00244338 https://hal.science/jpa-00244338}

Submitted on 1 Jan 1977

HAL is a multi-disciplinary open access archive for the deposit and dissemination of scientific research documents, whether they are published or not. The documents may come from teaching and research institutions in France or abroad, or from public or private research centers.
L'archive ouverte pluridisciplinaire HAL, est destinée au dépôt et à la diffusion de documents scientifiques de niveau recherche, publiés ou non, émanant des établissements d'enseignement et de recherche français ou étrangers, des laboratoires publics ou privés. 


\title{
ANALYSIS OF BEAMS FROM A DYNAMITRON \\ ACCELERATOR WITH A VIEW \\ TO MODIFICATION FOR HIGH PRECISION ELECTRON AND POSITIVE ION OPERATION
}

\author{
R. BASSETT
}

Radiation Centre University of Aston, Birmingham 315 2TT, Great Britain

Résumé. - Le Dynamitron 3 MV de Birmingham, qui est en mesure d'accélérer jusqu'à $10 \mathrm{~mA}$ d'électrons et $2 \mathrm{~mA}$ d'ions positifs a été étudié en vue d'améliorer la qualité du faisceau.

Dans le mode électron, le profil de faisceau a été observé en utilisant un écran fluorescent et les effets de différents champs oscillants mesurés en pulsant le faisceau à des fréquences d'accélérateur caractéristiques. Des oscillations HF et BF qui ont été identifiées, sont la cause d'une augmentation de la dimension intrinsèque du faisceau de $1 \mathrm{~mm}$ en diamètre à $10 \mathrm{~m}$ de distance, jusqu'à une enveloppe de $30 \mathrm{~mm}$. Nous faisons des suggestions de modifications qui doivent réduire ces effets.

Dans le mode proton, nous discutons l'utilisation d'un système d'analyse de masse à aimant permanent au terminal, des limitations et des problèmes d'alignement introduits par ce système.

Abstract. - The Birmingham Radiation Centre 3 MV Dynamitron, which is capable of accelerating up to $10 \mathrm{~mA}$ of electrons or $2 \mathrm{~mA}$ of positive ions, has been investigated with a view to improving the precision of its beam output.

In the electron mode the beam profile has been observed using a fluorescent screen and the effects of various oscillating fields measured by pulsing the beam at characteristic accelerator frequencies. Both $\mathrm{RF}$ and LF oscillations have been identified which cause the intrinsic beam size of $1 \mathrm{~mm}$ diameter at a distance of $10 \mathrm{~m}$ from the accelerator to expand to an envelope of about $30 \mathrm{~mm}$ diameter. Suggestions will be made of improvements to reduce these effects.

For proton operation the limitations of, and alignment problems introduced by, the use of a top terminal permanent magnet mass analysis system will be discussed. 